OBITUARY

\title{
David Francis Tyrie Nash: obituary and tribute
}

\section{INTRODUCTION}

David Nash died on 21 June 2017 having fought an unequal battle with cancer for several years. He was 68 (Fig. 1). At his packed Quaker funeral in Bristol he was remembered for his calm, non-judgemental support and advice to family, students and friends. He was fortunate to have enjoyed three parallel careers: as a teacher at Bristol University, as a geotechnical engineer with Arup and as a musician with a love of music and performance of the baroque repertoire at a high standard.

He is survived by his first wife Chloe and their daughter Rebecca (born 1982); and by his second wife Pip, her two daughters, Megan and Holly, and their daughter Sophie (born 2002).

\section{FAMILY AND MUSIC}

David was born in London on 20 December 1948, the eldest of four children. His parents, Kevin and Mel, were active members of the Society of Friends (Quakers) and met when singing in the 'International Choir' at the Penn Club a Quaker-run hostel - in London. They married in Dublin in 1947, and in 1952 decided to move out of London to Jordans, the Quaker-founded village in south Buckinghamshire, where they built the family home. Jordans is built around the old meeting house of 1688 and the older burial ground in which William Penn is buried. Jordans is also the location of the Mayflower barn, constructed (at least in part) from timbers of the Mayflower, in which many Quakers had crossed the Atlantic to begin a new life in North America. The Mayflower barn provided the venue through the 1960s for glorious annual series of summer concerts where it was possible to hear musicians of the calibre of George Malcolm, Peter Pears, Julian Bream and Paul Tortelier - for example as a matter of expectation. David and his sister Bridget moved there in 1953; Deb was born in 1954 and Beth in 1957. David grew up in Jordans and was a member of his local Friends' Meeting all his life.

From a very young age, David developed a precocious musical awareness and ability. Having mastered the operation of Kevin's record player he would offer visitors a choice - it might be Till Eulenspiegel or Scheherezade - and then put it on for them. He started learning the piano soon after moving to Jordans and took up the violin aged about 7. He received great encouragement from both parents. There was a family tradition of gathering in the parents' bed on Sunday mornings and singing hymns in four-part harmony (with Mel relegated to tenor). Hymns do not form part of regular Quaker worship, but were too good a source of fine harmonies to be neglected by Kevin and Mel. As the children grew up, the scope of family music-making widened to include quartets, quintets and madrigals. David was the acknowledged leader - partly because he was the oldest, but more because he played with maturity and confidence. Their house in Jordans was full of music - instrumental and choral groups often met there; children's concerts in the village hall gave many children the opportunity to perform in public; Mel taught piano to children and adults over a span of more than 50 years. Music was inescapable from all directions.

Having attended a local prep school to the age of 12, David won a music scholarship to Bryanston School, where he spent five happy years and flourished both academically and

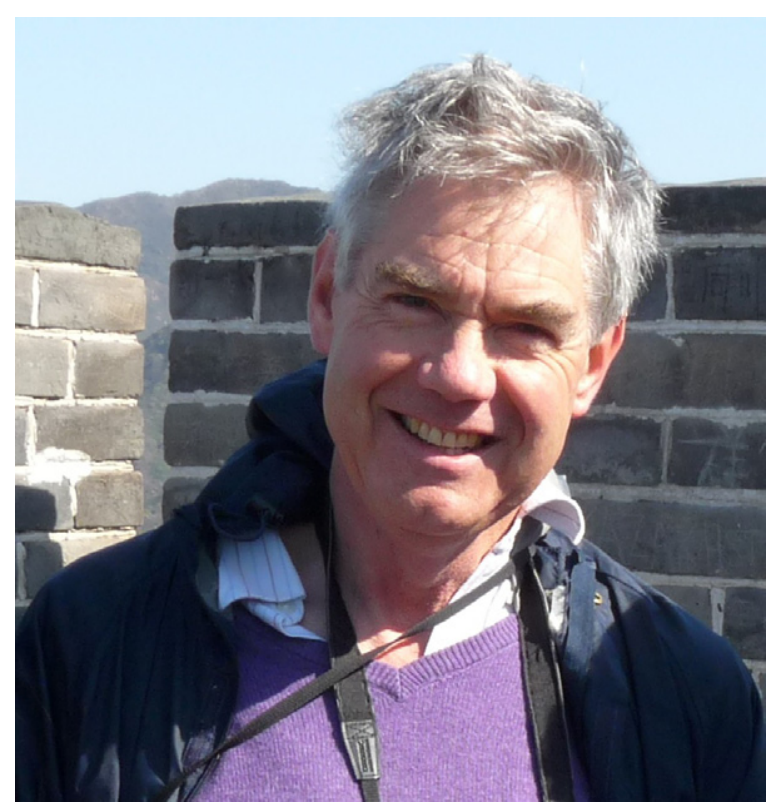

Fig. 1. David Nash (20 December 1948-21 June 2017) at the Great Wall, Beijing, 2012 (DMW)

musically. When a viola player was needed for a house music competition, David borrowed an instrument - and not long afterwards obtained a place as a viola player in the National Youth Orchestra (Fig. 2). He was proud to have played the Mozart Sinfonia Concertante for violin and viola with his violin teacher at the age of 15 . He had excellent opportunities to play and perform music, and some inspirational teachers, including an oboist maths teacher, who showed how music to a high standard could be retained as a hobby. During the final weeks of his life, David thought hard about the people who had inspired him as a musician and also as an engineer. He was from time to time confronted with the possibility of making music his exclusive career instead of geotechnical engineering, but in the end he was glad to have been able to do both.

\section{YOUTHFUL ENTERPRISE}

David also showed early talent in practical engineering again much encouraged by Kevin. Early projects included complicated Meccano constructions, and a large model lighthouse (some $1.2 \mathrm{~m}$ high) with a flashing light. The nearby London and North Eastern Railway line provided train-spotting opportunities: steam engines taking trains into or out of Marylebone. This was a somewhat passive activity; model railway circuits at 00 scale were also popular, but David wanted a more human scale. The garden became the railway network and David's sisters, on bicycles, were the trains. David, as 'Fat Controller', created a series of signals from bits of wood and string, controlled from the signal box (constructed above the dustbins). The 'unionised' drivers would protest if they were required to wait endlessly at stop signals, or were sent towards unavoidable head-on collisions.

He had a history of wind-powered devices. At home, an overhead 'railway' was built from the top of the garden to the 


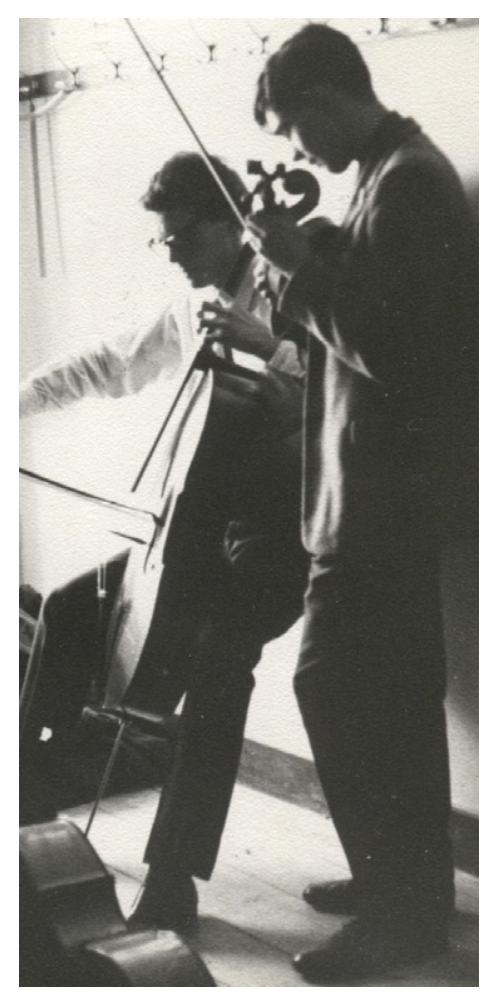

Fig. 2. National Youth Orchestra, 1966

tree house at the bottom. In theory, when the wind was in the right direction, the railway car would be blown up the wire against gravity. A more successful wind-taming project was his sand yacht (constructed from pram wheels, a plank or two, an oar for the mast and a table cloth for the sail). Seeking a pilot for the maiden voyage, Bridget and Deb were both found to be too heavy and the yacht sank into the sandanother geotechnical lesson, about the effect of shear stress on bearing capacity. Beth (aged about 4) then took the helm, and shot off over the beach, capsizing in the sand dunes, more or less as intended.

Every summer, the family spent a month or more in their cottage in Connemara, on the west coast of Ireland. They spent long days on a deserted beach, learning from Kevin how to dam the stream and 'messing about in boats'. David turned out to be a natural sailor, first learning to sail in a small, clinker-built dinghy, which was kept in the sand dunes and had to be rolled down to the sea on logs and launched over the breakers. He was never keen on team sports, but at Bryanston he was allowed to sail in Poole Harbour as an alternative to rugby or cricket.

As an adult, his passion for sailing was almost equal to his passion for music. His prize possession was his cherished Green Jacket, a Twister 28 which he kept at Portishead Marina. This required careful knowledge and respect for the huge tidal range of the Severn (typically around $12 \mathrm{~m}$ ). Misjudging the tide could mean sitting speculating on the mechanical properties of the soft mud (and hoping to remain upright) until being refloated by the incoming tide. He loved to tinker with the boat, and especially with its electronic systems, which always seemed to present him with new challenges. He was fascinated by all things nautical, and among his most prized possessions were the three volumes of the Admiralty handbook. He ensured that all the family knew semaphore, so that messages could be passed over long distances.

\section{CAMBRIDGE UNIVERSITY}

From Bryanston David went up to King's College, Cambridge University in 1966 with an entrance scholarship to read mechanical sciences (as engineering was coyly described). In those days, before the Joint Board of Moderators, there were two degree programmes in mechanical sciences. 'Gentlemen' took the normal (N) course sitting part I of the mechanical sciences tripos at the end of their third year to obtain the honours degree of Bachelor of Arts. Others (who were presumably not gentlemen) took the fast (F) course, sitting part I at the end of their second year and part II at the end of their third year, again emerging with the degree of Bachelor of Arts. Part II of the mechanical sciences tripos was the place where specialisation occurred. Students were able to sample from a potpourri of short units within a theme of, for example, civil and structural engineering, mechanical engineering, aerospace engineering and so on.

However, another possibility was to spend the third year studying a 1 year part I of a completely different tripos subject - in principle all that was required was a 'Certificate of diligent study'. David obtained a first class in mechanical sciences part I and then spent his third year reading archaeology and anthropology. This gave him ample time

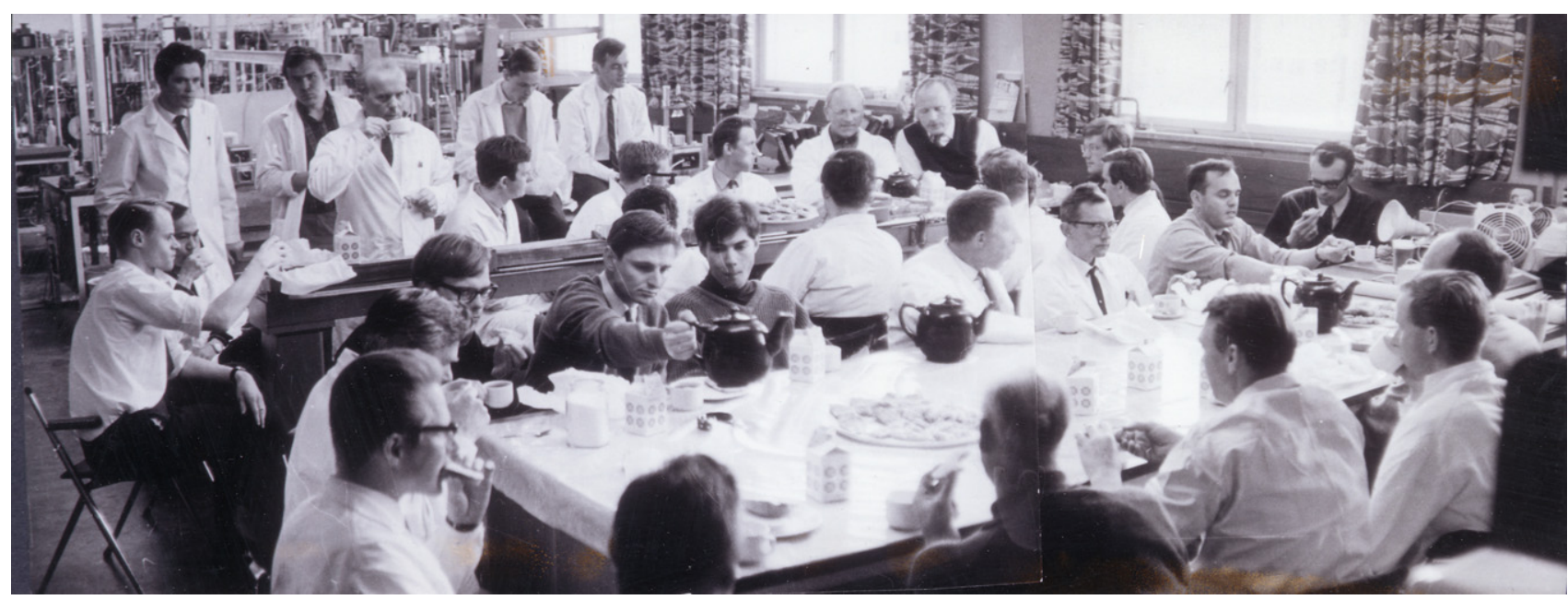

Fig. 3. David Nash (with teapots) at NGI in 1970 - the last lunch in the Forskningsveien site before NGI moved to their present location at Sognsveien 72, beside Ullevål Stadion (NGI) 
to sing as a volunteer in King's College chapel choir and to find numerous opportunities to play violin and viola in orchestral and chamber groups. Music-making led to the formation of many lifelong friendships. The Cambridge University Musical Society (CUMS) orchestra was conducted by David Willcocks; some concerts were conducted by Benjamin Britten; Mark Elder (who had also been at Bryanston), Andrew Davis and Andrew Wilson-Dickson were undergraduate conductors.

\section{NORWEGIAN GEOTECHNICAL INSTITUTE, OSLO}

On graduation, David worked for a year with the Norwegian Geotechnical Institute (NGI) in Oslo (Fig. 3). Kevin Nash was a close friend of Laurits Bjerrum, the founding director of NGI. They had worked together on the interpretation of hydraulic fracturing tests in the Dead Sea salt evaporation lagoon containment dykes. The Bjerrum and Nash families were good friends and spent holidays together.

At the time when David took part I of the mechanical sciences tripos, the only mention of soil mechanics was a short course of four lectures during the 'long vac term', during the long vacation between first and second years. He arrived in Oslo with this Cambridge engineering education, together with whatever knowledge of soil mechanics he had gleaned from his father's table or from beach-scale microgeotechnics on the Connemara coast. There would have been quite a contrast with the background of the (civil) engineers at NGI, many of whom would have graduated from the then Norges Tekniske Högskole (NTH) in Trondheim, having had a very solid 4 year grooming in engineering and 2 years of Nilmar Janbu's soil mechanics, plus several years' experience since graduation. It made sense for Bjerrum to offer David a job in the laboratory, working with Toralv Berre who (at 29) had just been put in charge.

He worked on a number of practical projects linked with the automation and control of the triaxial test, provision of sensors to measure the stresses, rate effects in triaxial and laboratory vane tests, the influence of initial stress state on subsequent stress-strain response, the effect of sampling and sample preparation procedure. Many of these themes resurfaced some years later in subsequent research in Bristol.

Bjerrum proposed that David should initially stay with him before moving to a room in one of the student villages, Kringsjå, at the end of the tram line, by the lake Sognsvann. He adapted to the Norwegian way of living and enjoyment of the outdoors very quickly. He achieved some fame and envy with his family and friends back in the UK with reports of commuting to work on skis (for part of the year).

\section{ARUP GEOTECHNICS}

Returning to London he filled the geotechnical gap by taking the Imperial College MSc in geotechnical engineering (Fig. 4). This fixed in his mind the crucial importance of observing and touching. This was something he tried to impart to students out in the field, whether engaged in surveying, or studies of engineering geology, water resources or slope stability. After completing his MSc, David worked for Binnie and Partners for a year before joining the London office of what subsequently became Arup Geotechnics, in 1972.

The geotechnical wing of Arup was expanding rapidly at this time. Support had to be maintained for design of foundations for the strongly structural work of the partnership. But an opportunity was seized to develop a portfolio of geotechnical skills and experience which found a more general civil (rather than structural) engineering

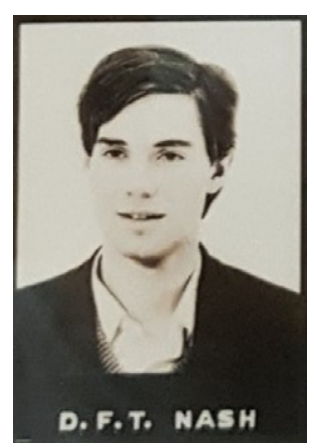

Fig. 4. Imperial College, 1970

application: projects involving, for example, tunnelling, roads, dams, earthquake engineering. The group was young, with a few wise men like David Henkel to keep them in check. Staff were expected to understand what they were doing, as well as the implications of what they were doing. David (Nash) was involved with the non-functioning dewatering system for the northern piers of the Thames Barrier - his proposal to unblock the flow by pouring in hydrochloric acid was very successful. He was sent to the Solomon Islands to advise on foundation design for a palm oil refinery. The plantation manager found it hard to accept that someone so youthful could be a qualified engineer (Fig. 5). The chosen central location for the refinery turned out to be underlain by soft clays and an alternative site capable of supporting shallow foundations had to be found. The site chosen for storage tanks turned out to coincide with a dump of intact (but empty) fizzy drink bottles, which was deemed adequate to support the modest applied loads.

In the mid-1970s the geotechnical group at Arup started working on major civil engineering works in South East Asia, often in partnership with contractors on design and construct projects. Arup were assisting on a tender for the east coast reclamation works on deep deposits of soft, normally consolidated marine clay in Singapore. Settlements were naturally a challenge, but in addition a bund was required to retain the fill. Marine clay had to be dredged to form a sand key for the bund. David (Nash) produced some extremely elegant calculations for the depth of key considering 'active' and 'passive' wedges in the marine clay either side of a central block beneath the bund, in which

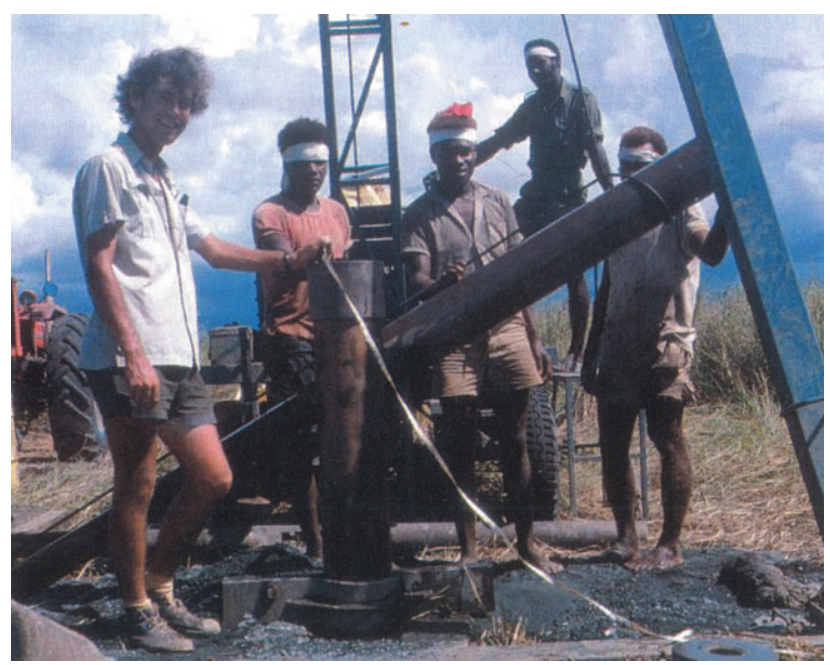

Fig. 5. Site investigation, Solomon Islands, 1974: the young geotechnical engineer (Arup Geotechnics) 
it was possible to allow for the anisotropy of undrained strength in the clay in different modes of shearing. This was something of a novelty for that time - perhaps a precursor of the ADP (Active-Direct simple shear-Passive) approach being developed at NGI to allow for anisotropy of undrained strength. The analysis greatly impressed David Henkel who, to say the least, was a difficult man to please. It also appealed to David (Nash)'s continuing interest in soft clays.

The partner contractor did not win the Singapore contract. However, they did win contract 106 for the Hong Kong metro system, which included Chater station (now Central station), which was the first and largest metro station on Hong Kong Island. It involved an excavation $500 \mathrm{~m}$ long and $27 \mathrm{~m}$ deep between diaphragm walls only a few metres away from high-rise buildings to the west and old colonial buildings to the east, which included the old Hong Kong Club and the Courts of Justice: two of the very few remaining old low-rise buildings in the centre of Hong Kong. The ground conditions were fill and sandy marine deposits over completely decomposed granite (CDG) about which very little was known, especially in response to deep excavations.

Diaphragm wall construction commenced in early 1977 near the Hong Kong Club. As the wall passed the building, significant settlements were reported, even though special precautions had been taken to keep the bentonite level in the trenches at least $2 \mathrm{~m}$ above the groundwater level (considered to be adequate to control trench stability). However, as the wall passed the Courts of Justice, building settlements of $80 \mathrm{~mm}$ were measured, causing severe cracking to the building. The project was then stopped and David Nash was sent out to investigate. He very carefully plotted all of the settlement data against the progress of wall construction and showed not only that the large settlements were the result of the cumulative effect of installing a series of panels, but also that settlements were extending up to $50 \mathrm{~m}$ from the wall, even though the panels were a maximum of $6 \mathrm{~m}$ wide. Cracking of old masonry was one problem; installation of diaphragm walls adjacent to existing high-rise buildings appeared potentially more challenging. Deep movements were occurring at low effective stress in the decomposed granite; the solution was to lower the groundwater level prior to installing the walls. The contractor was not impressed by this proposal, but David Henkel and others flew urgently out to Hong Kong and more or less confirmed David's diagnosis and remedy.

The identification and solution of the problem came from David's careful observations and painstaking plotting of all the data, a characteristic which would remain with him throughout his career. He had an uncanny ability to recognise which were the key observations and to deduce corresponding mechanisms of behaviour or misbehaviour.

He was a very hands-on engineer, whether writing his own software to control lab tests, or using a chainsaw to cut block samples in the middle of the night at the bottom of a deep excavation or helping Kevin in building the Connemara holiday cottage. In between overseas geotechnical excursions for Arup, he found time, with a colleague from the Chelsea Opera Group, to tackle the conversion of a four storey house in Canonbury (North London) into two two-storey maisonettes - each of which was to have a room large enough to house the Schubert octet. The project was completed successfully - and they remained close friends.

\section{BURO HAPPOLD}

Ted Happold left Arup in 1976 to take up a chair of architecture and engineering design at the University of Bath and, together with seven colleagues - several also from Arup - to create a new structural consultancy: Buro
Happold. In both teaching and practice, studios provided an environment in which specialists from all relevant cognate professions worked together in project teams. David left Arup in 1978 to join Bristol University. The geographical proximity made it easy for David to provide geotechnical support, over many years, for structural projects with anticipated geotechnical complications. Here are three examples of geotechnical complexity.

The construction of the basement to the Globe theatre on the south bank of the Thames, adjacent to Wren's house, required a diaphragm wall. The Thames was close on one side and two storeys of abandoned basement were discovered into which the bentonite slurry was only too happy to flow. The visibility of the site and the importance of Wren's house justified plenty of piezometers in the clay and gauges on the bracing to Wren's house itself. And the instrumentation was taken seriously.

Another basement at Bedfont Lakes was surrounded by offices built on the London Clay dug out of the Heathrow Terminal 5 tunnels and from the Jubilee line extension. This material was swelling, while the contractor was trying to compact it. Then the supply of disturbed London Clay was interrupted by the tunnel collapse in the centre of Heathrow airport. Heave of $115 \mathrm{~mm}$ was recorded in $6 \mathrm{~m}$ of London Clay fill. The trick was to assess the bulking effects on the imported clay fill of the reduced stresses and existing pore pressures and the shaking provided by the lorries transporting the clay extracted from the deep excavations for the new Jubilee line extension. A slightly sanitised version of this scenario turned up in a Bristol end-of-year examination.

The State Mosque of Sarawak required piled foundations down to the buried limestone karst formations, made more complicated by the presence of occasional igneous intrusions. These intrusions had damaged the calcareous materials, leaving them highly friable and soluble, and with rock-quality designation (RQD) around zero. David worked in partnership with Professor Chin of Malaysia to develop pragmatic solutions for the creation and testing of the various pile groups required throughout the site.

\section{BRISTOL UNIVERSITY}

He continued to act as a consultant to Arup and Buro Happold when he joined Bristol University as a lecturer in 1978. His long-running association with Arup enabled him to balance his academic work with real-world consulting. The insights gained from such projects often found their way into subsequent challenging exam questions. With his many contacts in industry, he started an industrial scholarship scheme that he ran for many years, which gave students regular vacation experience. Although he retired from Bristol in 2015, he continued to work closely with both Arup and the university, and remained delighted to talk about the details of laboratory research or the intricacies of engineering failure until a few weeks before his untimely death.

\section{KARAKORAM DEBRIS FLOW}

As a member of the 1980 international Karakoram earth sciences project in northern Pakistan, David had the opportunity to see geomorphological processes in action. Progress along the highway was blocked by a massive mud and debris flow, which surged down the hillside in pulses moving at around $100 \mathrm{~km} / \mathrm{h}$. The debris material was being eroded by the water flow from a glacier lake retained by an ice dam no longer high enough to withstand the water pressures at its base. A total quantity of some $2 \times 10^{6} \mathrm{~m}^{3}$ of debris was estimated to have travelled down the hillside in about $36 \mathrm{~h}$. The pulsing was the result of successive collapses of chunks 
of the side slopes of the narrow channel (or nullah) through which the debris was flowing. The debris coming to a halt formed another dam retaining a lake that had destroyed villages and fields. This dam was close to overtopping and shook like jelly with each new pulse of debris. Revisiting the site a few years later, the materials in the dam had drained and become exceedingly firm, and a mill had been established in the outflow channel. The scale and speed of this sudden event made the occasional collapse of coastal cliffs on the Isle of Wight seem really rather tame, but provided contrasting case histories for subsequent Bristol teaching.

\section{RESEARCH: SOFT CLAY AND BOTHKENNAR}

A task force chaired by Sir Alan Muir Wood reported to the Science and Engineering Research Council (SERC) in 1981 on priorities for civil engineering research. The task force noted the absence of large and full-scale facilities which could be used by industry and academics to explore and calibrate new models. Although there were various test sites around Britain presenting opportunities for field testing in various different types of soil, there was no well-characterised soft clay site. Peter Wroth, who was programme coordinator with George Milligan for the SERC geotechnical engineering steering group, came from a background of soft clay research, and was delighted with the possibility of belatedly joining other countries with soft clay test sites - such as Cubzac-les-Ponts (France), Åsrum (Norway), Skå-edeby and Bäckebol (Sweden) and St Alban (Quebec), among others.

A contract was awarded to Bristol University to identify the optimum location for the UK soft clay site: the team consisted of Bill Larnach, Brian Hawkins (1934-2016) (who taught engineering geology to civil engineering undergraduates in inimitable style over some five decades), David Nash and Isobel Lloyd as research assistant.

Site investigation data were reluctantly made available, by consultants and contractors, for various estuarine locations and a shortlist of four broad areas was identified: Thames estuary (one site), Severn estuary (two sites), Firth of Forth (one site). Subsequent piston sampling and cone penetration testing at these sites demonstrated that the soft soil at the Firth of Forth site, on the right bank not far upstream of Grangemouth, was certainly the most homogeneous of the four sites over a depth of some $20 \mathrm{~m}$. Sea level rise had been somewhat monotonic and steady, whereas at the other sites there had been significant pauses. The 11 ha site was purchased by the SERC in 1987 and named Bothkennar by David. An extremely extensive programme of in situ and laboratory testing was undertaken, leaving Bothkennar probably the most extensively characterised soft clay test site in the world. A series of papers describing the various programmes of sample recovery and testing in many research laboratories is included in a 'symposium in print' in the June 1992 issue of Géotechnique.

With nuclear submarine facilities in both the Firth of Forth and Firth of Clyde it was inevitable that local dog walkers would be suspicious of a notice on the gate to the Bothkennar site which included the address: Polaris House. A formal opening of the site by the local Labour MP followed by lunch in the adjacent hotel smoothed ruffled feathers. However, it turned out that the soft clay site was not actually satisfying a burning research need recognised by UK engineering companies or by UK academics. After a few projects - down-drag on piles, long-term loading of pad footings - the site was sold to the Royal Society for the Protection of Birds in 2001. It was an anomaly - albeit an inexpensive anomaly - on the Engineering and Physical
Sciences Research Council (EPSRC) inventory of capital assets.

Two other large-scale research facilities were constructed following the recommendation of the Muir Wood task force: the six-axis shaking table (earthquake simulator) at Bristol University and the flood channel facility at Hydraulics Research, Wallingford. Both of these fulfilled a recognised need for research and testing. In particular, consortia of hydraulics researchers at universities across the UK made sure that a series of collaborative research programmes made good use of the flood channel facility.

An opportunity after all to get dug into soft estuarine deposits came with the construction of motorway links to the second Severn crossing across the Severnside levels, accompanied by Engineering and Physical Sciences Research Council and industrial sponsorship from the Second Severn Crossing Group. Construction of road embankments with heights up to $9 \mathrm{~m}$ on the soft soils provided the usual challenges. Site investigation data were made available; an extensive programme of embankment monitoring included bespoke large strain extensometers designed specifically to provide reliable measurements of consolidation and creep settlements exceeding $1 \mathrm{~m}$.

In collaboration with Charles Hird (Sheffield University), state-of-the-art finite-element software was used in an attempt to model the chosen design solution to the problem of long-term settlement using vertical band drains, staged construction and surcharging. It became evident that the finite-element programs then available were quite unable to model long-term creep in anything other than a very simplistic way.

Accumulated understanding of various published creep models led to successful simulation of field observations. The Visual Basic program BRISCON distilled this accumulated knowledge in order to model fully coupled primary consolidation and long-term creep strain-rates for a column of soil around a vertical drain, combining classical work by Barron and by Hansbo on vertical drains with more recent creep modelling by Yin and Graham.

Some of the site investigation information was reused for undergraduate design exercises. And creep studies continued with tests on samples from Bothkennar that were waiting patiently for attention in the Bristol cold store.

\section{RESEARCH: STIFF CLAY:}

\section{LION YARD, CAMBRIDGE}

The Arup connection also gave access to extensive site information and monitoring data from the excavation for a multistorey underground car park at Lion Yard in the middle of Cambridge. The principal soil here is the stiff Cambridge Gault Clay for which such field observations and indeed such a construction type - were something of a novelty.

The first round of research was concerned with site observation and monitoring, laboratory testing and backanalyses. Lateral stresses were very low after diaphragm wall installation, resulting in smaller deflections, prop forces and bending moments than had been predicted. Wet concrete pressures recorded by the earth pressure cells during panel construction contributed to a better understanding of post-construction earth pressures and the effects of wall installation. The study of pressures within wet concrete and their variation with time and degree of cement hydration was an on-going research theme uncompleted at the time of David's death.

Redundancy of instrumentation helped to support equilibrium analyses which confirmed the deductions of active and passive lateral stresses on the wall outside and within the 
excavation. Pore pressure measurements confirmed the faster than anticipated drainage - with soil behaviour certainly not matching the undrained response often observed in similar construction in London Clay. Field monitoring with independent groups of instruments revealed the unreliability of estimation of bending moments based only on measurements of tensile strains in steel reinforcement.

The second round of research was more closely focused on the stiffness of the Gault Clay and the use of bender elements to monitor stiffness and change in stiffness, and the evolving anisotropy of stiffness of the stiff clay. This work has spread into most aspects of soil testing with different soils at Bristol, but the uncertainties of interpretation of the received signals to deduce shear wave velocities remain.

\section{RESEARCH: $\mathrm{PhD}$}

David's role as a $\mathrm{PhD}$ supervisor started long before the preparation of his own $\mathrm{PhD}$ thesis. The direction that he provided to his research students was generous, challenging and inspiring.

Never having had the opportunity to spend three or four years engaged in full-time research, he availed himself of the possibility of obtaining a $\mathrm{PhD}$ on the basis of published papers. He and his close colleague, Martin Lings, had worked on various projects together, publishing many jointly authored papers. This happy partnership culminated in the parallel submission of theses compiled from complementary sets of publications. These theses were successfully defended; David and Martin were awarded their PhD degrees in 2008.

\section{EDUCATOR}

Graduates may well recognise the names of research superstars past whom they have brushed in the corridors. However, they will actually remember the eccentric or dedicated (or eccentric and dedicated) lecturers who have been attempting to educate them over the previous 4 years. The assignment of numerical values and costs to aspects of education is not easy; rewarding numerical inputs and outputs of research seems more straightforward; the notion of universities as places of teaching and research, with these two components treated as equal partners, has slipped, and the essential and priceless contribution of the dedicated teacher has been overlooked.

David joined the Department of Civil Engineering at Bristol University as a lecturer in 1978 and retired (prematurely) as a senior lecturer in 2015. The research and publications were there, but his priority was to improve the educational experience of the undergraduates and to produce graduating civil engineers with confident and correct geotechnical understanding.

$\mathrm{He}$ insisted on including an initial course on soil mechanics and engineering geology in the first year of the undergraduate degree programme as a basis for the continuing courses in the second year, and also in order to maintain the profile of geotechnics alongside structures and water engineering. It also provided the opportunity for laboratory classes with a strong emphasis on hands-on activities - the description and classification of soil samples, and index tests. Incoming Erasmus exchange students had their first experiences of touching and testing real soils which rarely found a place in their home universities.

The importance of observation continued at every opportunity. The surveying field courses at Selworthy and subsequently Lyme Regis provided plenty of geological features to be explained as a distraction from staring through theodolites. David was a key member of the team that developed the 'Water resources project' - providing water for a (fictional) new town in mid-Wales. Students spent a full day in the field looking at rock exposures and identifying possible quarry locations, as well as identifying major disruptive geological features - ending with the discovery that Llyn Brianne dam had already been built.

An optional course on 'Slopes and dams' included a weekend field trip to the Isle of Wight. After plowtering around the landslide debris at St Catherine's Point and having observed the buildings suspended in mid-air at the cliff edge, students made some more or less realistic stability analyses and understood rather quickly that this might be an area to keep clear of in wet weather.

Once an Arup man, always an Arup man... Many problems of construction or other branches of engineering arise because adjacent professionals use very different languages. The potential for confusion grows if the two groups actually use the same word but with quite different meanings. Communication between architects and engineers is a particular example, which was close to Ove Arup's heart. Ian Duncan (1944-2016) ran a busy structural engineering consultancy in Bristol and also held a part-time senior lectureship at the university. David and Ian devised a course entitled 'Engineering architecture', which required students to understand the aims and intentions of architects and to be able to engage in confident discussion and criticism of individual buildings and townscapes. Communication was the first priority. Students were rewarded with a field trip which might be to Berlin or London Docklands or anywhere within economical reach and with bustling new structures penetrating the skyline. Practising architects joined in the campaign, using a range of tactics unfamiliar to civil engineering undergraduates to open their eyes to the language of architecture. Visiting architects found David himself very able to engage in the search for solutions to their current architectural challenges.

\section{ENGINEER}

David made hugely valuable contributions to many of the projects for which Arup's Bristol office was responsible, such as the geotechnical assessment of the proposed second Cheddar reservoir; the electrification of Victorian railway tunnels; and the deep basement of Bath's Southgate shopping centre. His unmistakeable patrician voice was often heard reviewing and providing advice concerning the geotechnical issues confronting the team. He seemed to have an effortlessly thorough understanding of soils and the engineering behind them, particularly their real-world foibles. His vast experience inspired confidence.

In his consulting work with Arup engineers, many of them Bristol graduates, he always seemed to have indefinite supplies of that uncosted resource: time. He was passionate about wanting his students to understand - and they were still his students whether at Arup or at the university. He was an infinitely patient teacher who loved to watch people learn. He always took whatever time was necessary to talk through anything that was unclear to his students. No question was too trivial or too difficult for him to attempt to answer.

David had some helpful, memorable phrases for geotechnical engineers: 'Plan for the worst and hope for the best'; 'Every site has a secret, you just have to find out what it is .... and there might be more than one'.

\section{MUSICIAN}

Performances in Cambridge in 1968 with Edward Higginbottom and the Purcell Society kindled his great enthusiasm for the exploration of baroque music using contemporary sources. Many evenings were spent discussing 


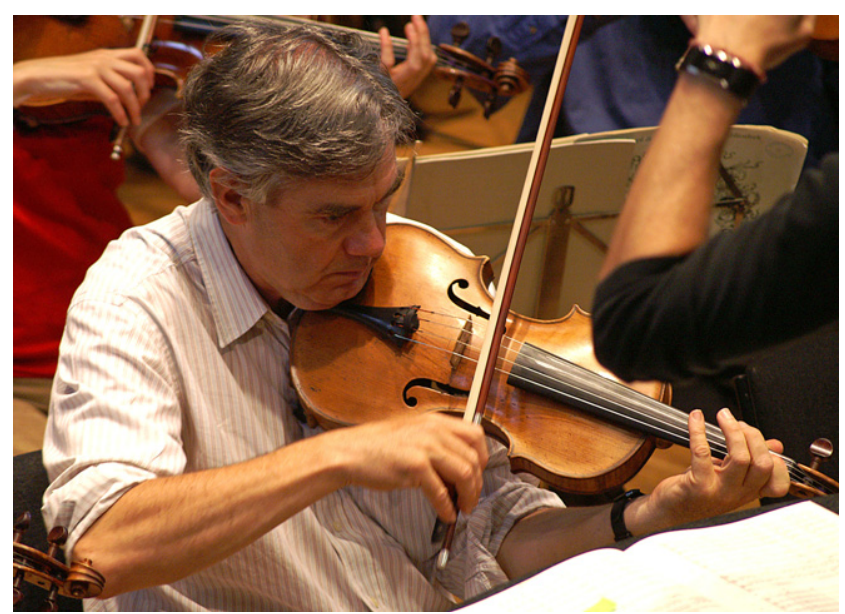

Fig. 6. Lead viola, Brandon Hill Chamber Orchestra, 2008 (John Lang)

alternative approaches with Tim Mason and Mark Elder. In Bristol, and before that in London, David took every opportunity to make music - in London he played with the Chelsea Opera Group and the Salomon orchestra. In the 1980s he was playing in the Eighteenth-Century Singers and Players, a group formed to educate players in the performance of baroque music, and subsequently in the Welsh Baroque Orchestra. This chamber group played all over Wales funded by the Welsh Arts Council and took Handel's Hercules to the Varazdin festival, Croatia. When external funding ceased in 2008, David worked hard to keep the orchestra alive.

Notwithstanding his youthful success with the Mozart Sinfonia concertante, David was an ensemble player rather than a soloist. He was much loved and greatly respected as a musician with accurate, clean and above all highly musical playing (Fig. 6). The front desk of the violas was a good place to be - in the middle of the orchestra. His seraphic smile, no matter how difficult the music, reflected his awareness that the orchestral and choral music was much more than the sum of the parts. Notes on the page were only part of the route by which the musical result was achieved. His profound love of the music always shone through and communicated itself to everyone around him. And at the end of a concert, despite the fact that he probably had the furthest to travel, there was somehow a reluctance to leave the ensemble and become an individual again. He lingered, helping get the harpsichord back into the car, folding up music stands and so on.

He organised a passionate and heartfelt performance of the $B$ minor Mass on 12 June 2016, in which members of the Welsh Baroque Orchestra joined the Brandon Hill Chamber Orchestra. The final applause was for Bach, of course, but also for David himself, who had acted as impresario for the event and for whom it was the final public concert performance. Nevertheless, even as personal discomfort increased and stamina decreased he would play chamber music at home with visiting musical friends - as he always had.

\section{ENVOI}

We have lost not just a dedicated educator, trusted engineer and talented musician, but also a brother, husband, father, uncle, tutor, counsellor, colleague, friend. He was an extraordinarily caring person, a dependable 'rock', confident and consistent and, in his last years, courageous. 'It is better

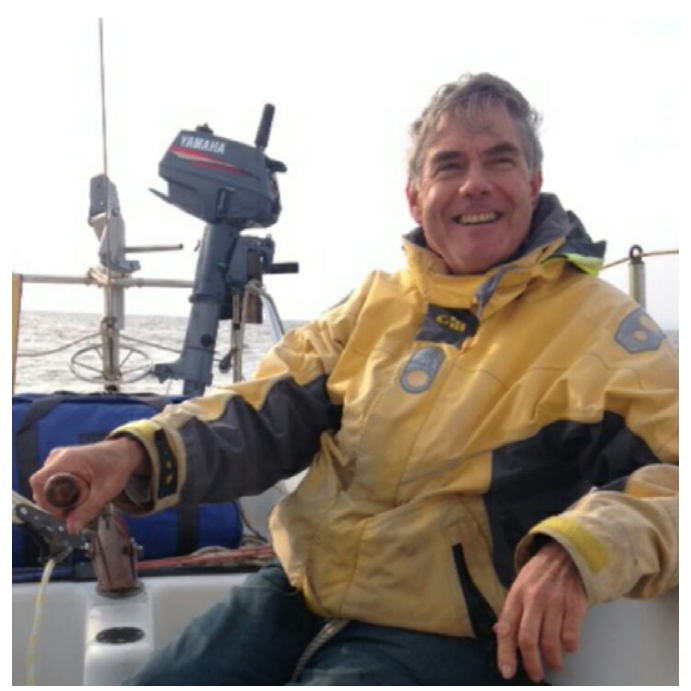

Fig. 7. Sailing in the Severn estuary, 2016 (Jonathan Berry)

to light one candle than to curse the darkness' (Chinese proverb).

As David's personal light faded so the construction of yet another extension to the Queen's Building (home of civil engineering and other parts of the university's Faculty of Engineering) was blocking the last vestigial rays of natural daylight from reaching the soil testing research laboratory. One could imagine David regretting the loss of the view across the city to the Mendip Hills beyond, congratulating the faculty on its continuing research and financial success, realising that the temperature control of the laboratories for long-term soil creep testing would be a little easier (every silver lining has its cloud), and then pedalling home to Clifton Vale and tackling some complex Bach keyboard music with friends or family.

'Happy is he who like Ulysses has returned having made a wonderful journey ...' (du Bellay, 1558). David was making three interleaved wonderful journeys but was not permitted to complete them: the tide was going out too fast (Fig. 7). At the end there remain these three: education, engineering and music. And the greatest of these three?

\section{ACKNOWLEDGEMENTS}

The author is very grateful to Jonathan Berry, Matthew Brown, Sarah D’Agostino (née Ryde), Jo Davidson (obituarist at King's College, Cambridge), Richard Davies, Bridget Day, Abby Fryett and others at Arup, Jim Hall, Sally Heslop, Benson Hsiung, the archivist at King's College, Cambridge, Suzanne Lacasse, John Lang, Martin Lings, Isobel Lloyd, Katie Melville, Saeed Mojabi, Pip Nash, Hugh Nettelfield, Lucy Robinson, Mike Shaw and Paul Vardanega for their assistance in preparing this obituary.

D. Muir Wood, University of Dundee, UK

\section{BIBLIOGRAPHY}

Bhattacharya, S., Nikitas, N., Alexander, N. A., Garnsey, J., Cox, J., Muir Wood, D. \& Nash, D. F. T. (2013). Observed dynamic soilstructure interaction in scale testing of offshore wind farm foundation. Soil Dynamics Earthquake Engng 54, 47-60.

Coburn, A. W., Hughes, R. E., Iiii, D., Nash, D. F. T. \& Spence, R. J. (1984). The construction and vulnerability to earthquakes of some building types in the northern area of Pakistan. In Proceedings of the international Karakoram project conference (ed. K. J. Miller), vol. 2, pp. 228-252. Cambridge, UK: Cambridge University Press. 
Corti, R., Diambra, A., Nash, D. F. T. \& Muir Wood, D. (2015). An evolving memory surface for modelling the cyclic behaviour of granular soils. In From fundamentals to applications in geotechnics: proceedings of the XVth pan-American conference on soil mechanics and geotechnical engineering (eds D. Manzanal and A. O. Sfriso), pp. 1001-1008. Amsterdam, the Netherlands: IOS Press.

Corti, R., Diambra, A., Muir Wood, D., Escribano, D. E. \& Nash, D. F. T. (2016). Memory surface hardening model for granular soils under repeated loading conditions. J. Engng Mech., ASCE 142, No. 12, 04016102.

Diambra, A., Ciavaglia, F., Harman, A., Dimelow, C., Carey, J. \& Nash, D. F. T. (2014). Performance of cyclic cone penetration tests in chalk. Géotechnique Lett. 4, No. 3, 230-237, https:// doi.org/10.1680/geolett.14.00050.

du Bellay, J. (1558). Heureux qui comme Ulysse a fait un beau voyage. In Les Regrets, sonnet XXXI. Paris, France: du Bellay (in French).

Ferreira, C., Viana Da Fonseca, A. \& Nash, D. F. T. (2011). Shear wave velocities for sample quality assessment on a residual soil. Soils Found. 51, No. 4, 683-692.

Flory, R. J. W., Nash, D. F. T., Hrachowitz, M., Hall, J. W. \& Walkden, M. J. A. (2001). The geomorphology and modelling of the landslide system at Walton-on-the-Naze. In Coastal rock slope instability - planning and management (eds R. N. Mortimore and A. Duperret), pp. 35-36. Le Havre, France: Université du Havre.

Flory, R. J. W., Nash, D. F. T., Lee, E. M., Hall, J. W., Walkden, M. J. A. \& Hrachowitz, M. (2002). The application of landslide modelling techniques for the prediction of soft coastal cliff recession. In Instability: planning and management seeking sustainable solutions to ground movement problems (eds R. G. McInnes and J. Jakeways), pp. 249-256. London, UK: Thomas Telford.

Greening, P. D., Nash, D. F. T., Ferreira, C., Benahmed, N. \& Da Fonseca, A. V. (2003). Comparison of shear wave velocity measurements in different materials using time and frequency domain techniques. In Proceedings of $3 r d$ international symposium on deformation characteristics of geomaterials, IS-Lyon03 (eds H. Di Benedetto, H. Geoffroy, T. Doanh and C. Sauzéat), vol. 1, pp. 380-386. Rotterdam, the Netherlands: Balkema.

Hawkins, A. B., Larnach, W. J., Lloyd, I. \& Nash, D. F. T. (1989). Selecting the location, and initial investigation of the SERC soft clay test bed site. Q. J. Engng Geol. 22, No. 4, 281-316.

Hawkins, A. B., Lloyd, I. M. \& Nash, D. F. T. (1991). The significance of mottling in the description of Quaternary estuarine soils. In Quaternary engineering geology: Proceedings of the 25th annual conference of the engineering group of the Geological Society (eds A. Forster, M. G. Culshaw, J. C. Cripps, J. A. Little and C. F. Moon), Engineering Geology Special Publications, note 7, pp. 637-642. London, UK: Geological Society.

Hight, D. W., Paul, M. A., Barras, B. F., Powell, J. J. M., Nash, D. F. T., Smith, P. R., Jardine, R. J. \& Edwards, D. H. (2003). The characterisation of the Bothkennar clay. In Characterisation and engineering properties of natural soils (eds T. Tan, K. K. Phoon, D. W. Hight and S. Leroueil), vol. 1, pp. 543-598. Rotterdam, the Netherlands: Balkema.

Hsiung, B. C., Nash, D. F. T., Tsai, W. S. \& Hwang, R. N. (1999). Observed behaviour of a deep excavation in Taipei. Proceedings of the civil and environmental engineering conference - new frontiers and challenges, Bangkok, Thailand, vol. 2, pp. 55-66.

Hsiung, B. C., Nash, D. F. T., Lings, M. L. \& Hsieh, H. S. (2001). Discussion: Effects of jet grouting on adjacent ground and structures [Wong and Poh]. J. Geotech. Geoenviron. Engng, ASCE 127, No. 12, 1076-1077.

Hughes, R. \& Nash, D. F. T. (1986). The Gupis debris flow and natural dam, July 1980. Disasters 10, No. 11, 8-14.

Kemp, M. J., Nash, D. F. T. \& Anderson, M. G. (1989). On modelling installation designs for soil water instrumentation, with particular reference to Casagrande type piezometer systems. Earth Surf. Processes Landforms 14, No. 5, 375-382.

Lings, M. L., Nash, D. F. T., Ng, C. W. W. \& Boyce, M. D. (1991). Observed behaviour of a deep excavation in Gault clay: a preliminary appraisal. In Proceedings of the 10th European conference on soil mechanics and foundation engineering (ed. Associazione Geotecnica Italiana), vol. 2, pp. 467-470. Rotterdam, the Netherlands: Balkema.

Lings, M. L., Nash, D. F. T. \& Ng, C. W. W. (1993). Reliability of earth pressure measurements adjacent to a multi-propped diaphragm wall. In Retaining structures: Proceeding of international conference, Cambridge, UK (ed. C. R. I. Clayton), pp. 258-269. London, UK: Thomas Telford.

Lings, M. L., Ng, C. W. W. \& Nash, D. F. T. (1994). The lateral pressure of wet concrete in diaphragm wall panels cast under bentonite. Proc. Instn Civ. Engrs - Geotech. Engng 107, No. 3, 163-172, https://doi.org/10.1680/igeng.1994.26469.

Lings, M. L., Nash, D. F. T. \& Hsiung, B. C. (1999). Discussion: Performance of diaphragm wall constructed using top-down method (Ou, Liao and Lin). J. Geotech. Geoenviron. Engng, ASCE 125, No. 12, 1100-1101.

Lings, M. L., Pennington, D. S. \& Nash, D. F. T. (2000). Anisotropic stiffness parameters and their measurement in a stiff natural clay. Géotechnique 50, No. 2, 109-125, https://doi.org/10.1680/ geot.2000.50.2.109.

Muir Wood, D. \& Nash, D. F. T. (2000). Earth pressures on an integral bridge abutment: a numerical case study. Soils Found. 40, No. 6, 23-38.

Muir Wood, D., Hu, W. \& Nash, D. F. T. (2000). Group effects in stone column foundations: model tests. Géotechnique 50, No. 6, 689-698, https://doi.org/10.1680/geot.2000.50.6.689.

Muir Wood, D., Lings, M. L., Nash, D. F. T. \& Gajo, A. (2001). Anisotropy of soils: laboratory measurements and constitutive implications. In Proceedings of 15th international conference on soil mechanics and geotechnical engineering (ed. Publication Committee of the 15th ICSMGE), vol. 1, pp. 321-324. Rotterdam, the Netherlands: Balkema.

Nash, D. F. T. (1987). A comparative review of limit equilibrium methods of slope stability. In Slope stability: geotechnical engineering and geomorphology (eds M. G. Anderson and K. S. Richards), pp. 11-75. Chichester, UK: Wiley.

Nash, D. F. T. (2001). Modelling the effects of surcharge to reduce long term settlement of reclamations over soft clays: a numerical case study. Soils Found. 41, No. 5, 1-13.

Nash, D. F. T. (2002). Closure to: modelling the effects of surcharge to reduce long term settlement of reclamations over soft clays: a numerical case study. Soils Found. 42, No. 5, $121-124$.

Nash, D. F. T. (2010). Influence of destructuration of soft clay on time-dependant settlements. In Proceedings of the 7th European conference on numerical methods in geotechnical engineering, Trondheim, Norway (eds T. Benz and S. Nordal), pp. 75-80. London, UK: Taylor \& Francis Group.

Nash, D. F. T. (2012a). Activities to enhance students' understanding of pore water pressure, seepage and total head. In Shaking the foundations of geo-engineering education (eds B. McCabe, M. Pantazidou and D. Phillips), pp. 143-148. London, UK: Taylor \& Francis Group.

Nash, D. F. T. (2012b). Integrating professional geotechnical practice into the curriculum. In Shaking the foundations of geo-engineering education (eds B. McCabe, M. Pantazidou and D. Phillips), pp. 287-294. London, UK: Taylor \& Francis Group.

Nash, D. F. T. \& Brown, M. A. (2012). A comparison of four elastic visco-plastic models for soft clay. In Constitutive modeling of geomaterials: advances and new applications (eds Q. Yang, J. M. Zhang, H. Zheng and Y. Yao), pp. 121-124. Berlin, Germany: Springer.

Nash, D. F. T. \& Brown, M. (2015). The influence of destructuration of soft clay on time-dependent settlements: comparison of some elastic viscoplastic models. Int. J. Geomech. 15, No. 5, A4014004.

Nash, D. F. T. \& Duffin, M. J. (1982). Site investigation of glacial soils using cone penetration tests. In Penetration testing: proceedings of the 2nd European symposium (eds A. Verruijt, F. L. Beringen and E. H. de Leeuw), vol. 2, pp. 733-738. Rotterdam, the Netherlands: Balkema.

Nash, D. F. T. \& Greening, P. D. (2004). Frequency domain determination of $G_{0}$ using bender elements. Geotech. Testing $J$. 27, No. 3, 27-30. 
Nash, D. F. T. \& Ryde, S. J. (1999). Modelling the effects of surcharge to reduce long term settlement of an embankment on soft alluvium. In Geotechnical engineering for transportation: proceedings of the 13th European conference on soil mechanics and foundation engineering (eds F. B. J. Barends, J. Lindenberg, H. J. Luger, A. Verruijt and L. de Quelerij), vol. 3, pp. 1555-1561. London, UK: Taylor \& Francis Group/CRC Press.

Nash, D. F. T. \& Ryde, S. J. (2000). Modelling the effects of surcharge to reduce long term settlement of reclamations over soft clays. In Coastal geotechnical engineering in practice, IS-Yokohama 2000 (eds A. Nakase and T. Tsuchida), pp. 483-488. Rotterdam, the Netherlands: Balkema.

Nash, D. F. T. \& Ryde, S. J. (2001). Modelling consolidation accelerated by vertical drains in soils subject to creep. Géotechnique 51, No. 3, 257-273, https://doi.org/10.1680/ geot.2001.51.3.257.

Nash, D. F. T. \& Spence, R. J. (1984). Experimental studies of the effect of earthquakes on small adobe and masonry buildings. In Proceedings of the international Karakoram project conference (ed. K. J. Miller), vol. 1, pp. 245-252. Cambridge, UK: Cambridge University Press.

Nash, D. F. T., Brunsden, D. K., Hughes, R. E., Jones, D. K. C. \& Whalley, B. F. (1985). A catastrophic debris flow near Gupis, northern Pakistan. In Proceedings of the 11th international conference on soil mechanics and foundation engineering (ed. Publications Committee of the 11th ICSMFE), vol. 3, pp. 1163-1166. Rotterdam, the Netherlands: Balkema.

Nash, D. F. T., Powell, J. J. M. \& Lloyd, I. M. (1992a). Initial investigations of the soft clay test site at Bothkennar. Géotechnique 42, No. 2, 163-181, https://doi.org/10.1680/ geot.1992.42.2.163.

Nash, D. F. T., Sills, G. C. \& Davison, L. R. (1992b). One-dimensional consolidation testing of soft clay from Bothkennar. Géotechnique 42, No. 2, 241-256, https://doi.org/ 10.1680/geot.1992.42.2.241.

Nash, D. F. T., Lings, M. L. \& Ng, C. W. W. (1996). Observed heave and swelling beneath a deep excavation in Gault clay. In Geotechnical aspects of underground construction in soft ground: proceedings of the international symposium (eds R. J. Mair and R. N. Taylor), pp. 191-196. Rotterdam, the Netherlands: Balkema.

Nash, D. F. T., Lings, M. L. \& Jefferis, S. A. (1997). Hydrogen sulphide generation beneath a deep basement in Gault clay. In Ground chemistry implications for construction: proceedings of international conference on the implications of ground chemistry and microbiology for construction (ed. A. B. Hawkins), pp. 187-196. Rotterdam, the Netherlands: Balkema.

Nash, D. F. T., Lings, M. L. \& Pennington, D. S. (1999). The dependence of anisotropic $G_{\mathrm{o}}$ shear moduli on void ratio and stress state for reconstituted Gault clay. In Pre-failure deformation characteristics of geomaterials: proceedings of 2nd international symposium, Turin, Italy (eds M. Jamiolkowski, R. Lancellota and D. Lo Presti), vol. 1, pp. 229-238. Rotterdam, the Netherlands: Balkema.
Nash, D. F. T., Lings, M. L., Benahmed, N., Sukolrat, J. \& Muir Wood, D. (2007a). The effects of controlled destructuring on the small strain shear stiffness $G_{0}$ of Bothkennar clay. In Soil stress-strain behaviour: measurement, modelling and analysis, geotechnical symposium, Rome, Italy (eds H. I. Ling, L. Callisto, D. Leshchinsky and J. Koseki), pp. 287-298. Dordrecht, the Netherlands: Springer.

Nash, D. F. T., Sukolrat, J., Greening, P. D. \& Benahmed, N. (2007b). Comparison of shear wave velocity measurements in a soft clay specimen using time and frequency domain techniques. Rivista Italiana di Geotecnica 25, No. 2, 56-68.

Nash, D. F. T., Lings, M. L., Benahmed, N. \& Sukolrat, J. (2008). Comparison of field and laboratory-derived shear wave velocity profiles in Bothkennar clay. In Proceedings of the 4th international symposium on deformation characteristics of geomaterials (eds S. E. Burns, P. W. Mayne and J. C. Santamarina), vol. 1, pp. 183-190. Amsterdam, the Netherlands: IOS Press.

Ng, C. W. W., Lings, M. L. \& Nash, D. F. T. (1992). Back-analysing the bending moment in a concrete diaphragm wall. Struct. Engr 70, No. 23 and 24, 421-426.

Ng, C. W. W., Lings, M. L., Simpson, B. \& Nash, D. F. T. (1995) An approximate analysis of the three-dimensional effects of diaphragm wall installation. Géotechnique 45, No. 3, 497-507, https://doi.org/10.1680/geot.1995.45.3.497.

Ng, C. W. W., Lings, M. L., Simpson, B. \& Nash, D. F. T. (1996). Discussion: An approximate analysis of the three-dimensional effects of diaphragm wall installation. Géotechnique 46, No. 4, 775-777, https://doi.org/10.1680/geot.1996.46.4.775.

Ng, C. W. W., Simpson, B., Lings, M. L. \& Nash, D. F. T. (1998). Numerical analysis of a multipropped excavation in stiff clay. Can. Geotech. J. 35, No. 1, 115-130.

Pennington, D. S., Nash, D. F. T. \& Lings, M. L. (1997). Anisotropy of $G_{0}$ shear stiffness in Gault Clay. Géotechnique 47, No. 3, 391-398, https://doi.org/10.1680/geot.1997.47.3.391.

Pennington, D. S., Nash, D. F. T. \& Lings, M. L. (2001) Horizontally mounted bender elements for measuring anisotropic shear moduli in triaxial clay specimens. Geotech. Testing J. 24, No. 2, 133-144.

Sukolrat, J., Nash, D. F. T., Lings, M. L. \& Benahmed, N. (2006). The assessment of destructuration of Bothkennar clay using bender elements. In Soft soil engineering: proceedings of the 4th international conference (eds D. H. Chan and K. T. Law), pp. 471-482. Leiden, the Netherlands: Balkema.

Sukolrat, J., Nash, D. F. T. \& Benahmed, N. (2008). The use of bender elements in the assessment of disturbance of soft clay samples. In Proceedings of the 3rd international conference on geotechnical and geophysical site characterization (eds A. B. Huang and P. W. Mayne), pp. 1489-1495. Taylor and Francis Group.

Yuan, Y., Whittle, A. J. \& Nash, D. F. T. (2015). Model for predicting and controlling creep settlements with surcharge loading. In Deformation characterisation of geomaterials: proceedings of the 6th international symposium (eds V. A. Rinaldi, M. E. Zaballos and J. J. Claria), pp. 931-938. Amsterdam, the Netherlands: IOS Press. 